University of Wollongong

Research Online

Faculty of Engineering and Information

Faculty of Engineering and Information

Sciences - Papers: Part A

Sciences

$1-1-2013$

\title{
Understanding the factors controlling the removal of trace organic contaminants by white-rot fungi and their lignin modifying enzymes: A critical review
}

\author{
Shufan Yang \\ University of Wollongong, sy527@uowmail.edu.au \\ Faisal I. Hai \\ University of Wollongong, faisal@uow.edu.au \\ Long D. Nghiem \\ University of Wollongong, longn@uow.edu.au \\ William E. Price \\ University of Wollongong, wprice@uow.edu.au \\ Felicity Roddick \\ Royal Melbourne Institute Of Technology
}

See next page for additional authors

Follow this and additional works at: https://ro.uow.edu.au/eispapers

Part of the Engineering Commons, and the Science and Technology Studies Commons

Research Online is the open access institutional repository for the University of Wollongong. For further information contact the UOW Library: research-pubs@uow.edu.au 


\title{
Understanding the factors controlling the removal of trace organic contaminants by white-rot fungi and their lignin modifying enzymes: A critical review
}

\author{
Abstract \\ White-rot fungi (WRF) and their lignin modifying enzymes (LME) can degrade a wide range of trace \\ organic contaminants (TrOC), which are suspected to cause adverse health effects in humans and other \\ biota. Recent studies have successfully applied either whole-cell WRF or their extracellular culture extract \\ to remove TrOC from the aqueous phase. TrOC removal by a WRF system is dependent on a range of \\ factors including molecular structure of the TrOC, fungal species and their specific LME, culture medium \\ composition, and methods to enhance fungal degradation capacity; however, the specific relationships \\ between these factors have not been systematically delineated. The aim of this review paper is to fill this \\ important gap in the literature by critically analysing the ability of WRF and their LME specifically to \\ remove TrOC. Mechanisms and factors governing the degradation of TrOC by WRF and their LME are \\ reviewed and discussed. (C) 2013 Elsevier Ltd.
}

\section{Keywords}

contaminants, organic, trace, removal, controlling, review, critical, enzymes, modifying, lignin, factors, their, understanding, fungi, rot, white

\section{Disciplines \\ Engineering | Science and Technology Studies}

\section{Publication Details}

Yang, S., Hai, F. I., Nghiem, L. D., Price, W. E., Roddick, F., Moreira, M. T. \& Magram, S. F. (2013). Understanding the factors controlling the removal of trace organic contaminants by white-rot fungi and their lignin modifying enzymes: A critical review. Bioresource Technology, 141 97-108.

\section{Authors}

Shufan Yang, Faisal I. Hai, Long D. Nghiem, William E. Price, Felicity Roddick, Maria T. Moreira, and Saleh F. Magram 


\title{
Understanding the factors controlling the removal of trace organic contaminants by white- rot fungi and their lignin modifying enzymes: a critical review
}

\author{
Shufan Yang ${ }^{\text {a }}$, Faisal I. Hai ${ }^{\mathrm{a}, *}$, Long D. Nghiem ${ }^{\mathrm{a}}$, William E. Price ${ }^{\mathrm{b}}$, Felicity Roddick ${ }^{\mathrm{c}}$, Maria T. Moreira ${ }^{\mathrm{d}}$ and \\ Saleh F. Magram ${ }^{\mathrm{e}}$ \\ ${ }^{a}$ Strategic Water Infrastructure Laboratory, School of Civil, Mining and Environmental Engineering, University of \\ Wollongong, Wollongong, NSW 2522, Australia \\ ${ }^{\mathrm{b}}$ Strategic Water Infrastructure Laboratory, School of Chemistry, The University of Wollongong, NSW 2522, \\ Australia \\ ${ }^{\mathrm{c}}$ School of Civil, Environmental and Chemical Engineering, RMIT University, 124 La Trobe Street, Melbourne, \\ Victoria 3001, Australia \\ ${ }^{\mathrm{d}}$ Department of Chemical Engineering, School of Engineering, University of Santiago de Compostela, Santiago de \\ Compostela 15782, Spain \\ ${ }^{\mathrm{e}}$ Department of Civil Engineering, King Abdul Aziz University, Jeddah 21589, Saudi Arabia \\ * Corresponding author
}

\begin{abstract}
White-rot fungi (WRF) and their lignin modifying enzymes (LME) can degrade a wide range of trace organic contaminants (TrOC), which are suspected to cause adverse health effects in humans and other biota. Recent studies have successfully applied either whole-cell WRF or their extracellular culture extract to remove TrOC from the aqueous phase. TrOC removal by a WRF system is dependent on a range of factors including molecular structure of the TrOC, fungal species and their specific LME, culture medium composition, and methods to enhance fungal degradation capacity; however, the specific relationships between these factors have not been systematically delineated. The aim of this review paper is to fill this important gap in the literature by critically analysing the ability of WRF and their LME specifically to remove TrOC. Mechanisms and factors governing the degradation of TrOC by WRF and their LME are reviewed and discussed.
\end{abstract}

Keywords: white-rot fungi; lignin modifying enzymes; trace organic contaminants; chemical structure; biodegradation; biosorption.

* Corresponding author: Faisal I. Hai, E-mail: faisal@uow.edu.au; Phone: +61 242213054 


\section{$\underline{\text { Table of content }}$}

\section{Introduction}

2 White-rot fungi (WRF) and their enzyme systems

3Effect of TrOC properties on removal

3.1 Molecular structure

3.1.1 TrOC with strong electron donating group (EDG)

3.1.2 TrOC with strong electron withdrawing group (EWG)

3.1.3 Combined effect of EDG and EWG

3.2 TrOC hydrophobicity

\section{Effect of fungal species}

5 TrOC removal by extracellular lignin modifying enzymes (LME)

5.1 Effect of enzyme types

5.2 Effect of addition of redox mediators

5.3 Effect of immobilization of enzyme

6 Effect of physicochemical properties of wastewater matrix

7 Removal mechanisms and degradation pathways

7.1 Removal mechanisms

7.2 Degradation pathways

8 Future scope of research

9 Conclusion 


\section{Introduction}

Trace organic contaminants (TrOC) such as pharmaceuticals and personal care products (PPCPs) and endocrine disrupting chemicals (EDCs) are biologically active and can thus present a threat to the aquatic environment with effects such as acute and chronic toxicity to aquatic organisms, accumulation in the ecosystem and loss of habitats and biodiversity, as well as a range of possible adverse effects on human health. Due to inefficient removal by conventional wastewater treatment plants, some TrOC have been frequently detected in wastewater-impacted water sources around the world (Alexander et al., 2012; Jones et al., 2005). Although they occur in the environment at concentrations ranging from a few nanograms to several micrograms per litre, TrOC may still cause harm to aquatic species. For instance, the synthetic steroid hormone 17aethynylestradiol, which is widely used in the contraceptive pill, can impose detrimental endocrine disrupting effects on fish and other aquatic organisms at concentrations as low as several ng/L. Adverse toxicological effects of PPCPs and EDCs on human health such as inhibited growth of human embryonic kidney cells, reduction in mean birth weight and neurotoxicity have also been reported (Alexander et al., 2012). A further concern is the synergistic effect of mixtures of TrOC (Jones et al., 2005). Although effects of individual substances may be insignificant, long-term exposure to a mixture of TrOC may have health effects on human and other biota (Jones et al., 2005).

Common biological wastewater treatment processes such as the conventional activated sludge or membrane bioreactor processes have been reported to efficiently remove significantly hydrophobic and/or easily biodegradable TrOC such as ibuprofen and bisphenol A. However, poor and/or unstable removal of significantly hydrophilic and biologically persistent TrOC such as carbamazepine and diclofenac has also been reported (Suárez et al., 2008). Recently there has been much interest in white-rot fungi (WRF) due to their unique capacity to degrade TrOC (Marco-Urrea et al., 2010a; Rodarte-Morales et al., 2011; Rodríguez-Rodrígueza et al., 2011; Tran et al., 2010). WRF are a type of fungus that can degrade lignin, a complex natural compound which forms the hard cover that protects soft wood, by nonspecific extracellular enzymes. In addition to the application of whole-cell preparations an alternative, which decouples the fungal growth and bioremediation stages, is to utilise extracellular culture extract 
('crude enzyme') or purified enzymes. WRF and their lignin modifying enzymes (LME) have been reported to degrade pollutants that are not amenable to bacterial degradation such as azo dyes, polycyclic aromatic hydrocarbons, chlorophenols, nitrotoluenes and polychlorinated biphenyls (Hai et al., 2007; Reddy, 1995). Several recent batch experiments have shown excellent TrOC removal by either whole-cell WRF or their LME (Hata et al., 2010a; Kim \& Nicell, 2006a; Rodarte-Morales et al., 2011). For example, WRF treatment has been reported to achieve efficient degradation of a range of PPCPs and EDCs including diclofenac, carbamazepine, naproxen and 17 $\alpha$-ethynylestradiol (Hata et al., 2010a; Kim \& Nicell, 2006a; Rodarte-Morales et al., 2011), while the bacterial degradation of these compounds has been characterized by negligible kinetic biodegradation constants (Suárez et al., 2008).

The TrOC removal performance of a WRF system depends on various factors including the chemical structure of the TrOC, fungal species and their specific LME, culture medium, and methods to enhance fungal degradation capacity; however, the interdependence of these factors is yet to be systematically documented. This review paper critically analyses the ability of WRF and their LME to remove TrOC.

\section{White-rot fungi (WRF) and their enzyme systems}

WRF secrete three main classes of LME: lignin peroxidases (LiPs), manganese-dependent peroxidases (MnPs) and laccase (Reddy, 1995). LiP, known as ligninase or diarylopropane oxygenase, was first isolated from the WRF Phanerochaete chrysosporium (Karam \& Nicell, 1997) in 1983. LiP was shown to eliminate a variety of recalcitrant aromatic compounds including polycyclic aromatic and phenolic compounds (Reddy, 1995). MnP is a heme glycoprotein enzyme first isolated from $P$. chrysosporium, which has been observed to catalyse the oxidation of several monoaromatic phenols and aromatic dyes (Karam \& Nicell, 1997); however these reactions required the presence of divalent manganese and certain types of buffers. Laccases (benzenediol: oxygen oxidoreductase) are copper-containing enzymes which can oxidise various chemicals such as diphenols, methoxy-substituted monophenols and aromatic and aliphatic amines (Reddy, 1995). Laccase operates catalytically via the four-electron reduction of $\mathrm{O}_{2}$ to $\mathrm{H}_{2} \mathrm{O}$, resulting in the oxidation of hydrogen-donating substrates. Theoretically, laccase can oxidise any substrate with similar characteristics to diphenol. The redox potential of 
specific laccases can vary depending on the fungal source. Some high redox potential fungal laccases can also oxidise monophenols, while some have been shown to be capable of oxidation of other groups of chemicals such as benzenethiols, carbonylic products and benzyl alcohols (Mayer \& Staples, 2002). It is interesting to note that although a fungal species can potentially secrete all three enzymes, namely, laccase, MnP and LiP, a particular strain may not secrete all of them. For instance, although Trametes versicolor has been associated with all three enzymes (Bending et al., 2002; Cajthaml et al., 2009a), the strain ATCC 7731 secretes mostly laccase (Yang, 2012b). The secretion of specific enzymes may also depend on culture conditions including the composition of the growth medium. In addition, WRF secrete low molecular weight mediators which enlarge the range of compounds they are able to degrade (Marco-Urrea et al., 2010a). Apart from the extracellular enzymes, intracellular enzyme systems, such as cytochrome P450, have been reported to play important roles in the removal of some TrOC (Golan-Rozen et al., 2011).

\section{Effect of TrOC properties on removal}

The removal of TrOC by WRF treatment varies widely from compound to compound. The physicochemical properties of the target molecules appear to be a key reason for such variation: some TrOC are easily biosorbed due to their high hydrophobicity; some have molecular features that render them readily biodegradable by WRF, while others are resistant to the WRF enzyme system due to certain features of their molecular structure.

\subsection{Molecular structure}

The presence of electron withdrawing functional groups $(\mathrm{EWG})$ such as amide $\left(-\mathrm{CONR}_{2}\right)$, carboxylic $(-\mathrm{COOH})$, halogen $(-\mathrm{X})$, and nitro $\left(-\mathrm{NO}_{2}\right)$ group generates an electron deficiency and thus renders the compounds less susceptible to oxidative catabolism. Electron donating functional groups (EDG) such as amine $\left(-\mathrm{NH}_{2}\right)$, hydroxyl $(-\mathrm{OH})$, alkoxy $(-\mathrm{OR})$, alkyl (-R) and acyl (-COR) group on the other hand, render the molecules more prone to electrophilic attack by oxygenases of aerobic bacteria (Tadkaew et al., 2011). In line with this concept, Table 1 presents widely studied and representative TrOC in four categories based on the relationship of their chemical structures (EDG and/or EWG) and removal by WRF. 


\section{Table 1}

\subsubsection{TrOC with strong EDG}

In general, compounds with strong electron donating groups such as hydroxyl (-OH) and amine $\left(-\mathrm{NH}_{2}\right)$ have been found to be extensively/effectively removed. For example, WRF have demonstrated high removal of phenolic compounds such as nonylphenol (Junghanns et al., 2005; Soares et al., 2006), bisphenol A (Cajthaml et al., 2009a; Hirano et al., 2000; Lee et al., 2005; Lee et al., 2004; Yang et al., 2012a), and bisphenol B (Tsutsumi et al., 2001), bisphenol F (Tsutsumi et al., 2001), as well as hormones (Cajthaml et al., 2009a; Tamagawa et al., 2005), all of which have hydroxyl group(s) $(-\mathrm{OH})$ in their structure. The effect of the amine group as an EDG has been discussed in Section 3.1.3.

Nonylphenol is a surfactant which has been observed to be easily removed from the aqueous phase by WRF treatment. Several studies, in which the initial concentration of nonylphenol varied over a wide range $(2.9$ - 3,000 $\mu \mathrm{g} / \mathrm{L})$, have reported high removal efficiency (from $85 \%$ to $100 \%$ ) by various fungal species including T. versicolor, P. chrysosporium, Bjerkandera adusta, Irpex lacteus and Pycnoporus cinnabarinus (Cajthaml et al., 2009a; Junghanns et al., 2005; Soares et al., 2006). Bisphenol A and other bisphenol derivatives (e.g. bisphenol B and bisphenol F) were also efficiently removed. During independent investigations using a concentration range of 5 to $500 \mu \mathrm{g} / \mathrm{L}$, bisphenol A was removed by more than $95 \%$ in the majority of the studies (Cabana et al., 2007a; Cajthaml et al., 2009a; Fukuda et al., 2001; Kim \& Nicell, 2006a; Lee et al., 2005; Nicolucci et al., 2011; Tsutsumi et al., 2001; Yang et al., 2012a). Bisphenol B and bisphenol $\mathrm{F}$ were removed by more than $91 \%$ using a concentration range of 188 to $299 \mu \mathrm{g} / \mathrm{L}$ (Nicolucci et al., 2011).

It is noteworthy that the nature of other substituent groups in the ring structure of TrOC containing an $-\mathrm{OH}$ group may affect TrOC removal. For example, Cajthaml et al. (2009a) showed that, there was no removal of linear nonylphenol (4-n-nonylphenol) by $T$. versicolor but branched nonylphenol (4-nonylphenol) was completely removedunder the same conditions. 17 $\beta$ estradiol and $17 \alpha$-ethinylestradiol have basically the same chemical structure, except the ethinyl group present in $17 \alpha$-ethinylestradiol, which leads to poor bacterial degradation of the latter (Hai et al., 2012 ). However, both $17 \beta$-estradiol and 17 $\alpha$-ethinylestradiol have been reported to be 
efficiently degraded by different WRF species, including B. adusta, Dichomitus squalens, I. lacteus and Pycnoporus cinnabarinus (Cajthaml et al., 2009a; Suzuki et al., 2003).

\subsubsection{TrOC with strong EWG}

Compounds containing strong EWG have been found difficult to eliminate (Table 1). A classical example of a TrOC highly resistant to bacterial degradation is carbamazepine (Hai et al., 2012 ; Suárez et al., 2008) which contains an amide (azepine) group (strong EWG). Marco-Urrea et al. (2009) reported low or no removal of carbamazepine by WRF species such as I. lacteus ( $2 \%$ ) and $P$. chrysosporium $(0 \%)$ when an initial concentration of $10 \mathrm{mg} / \mathrm{L}$ of the compound was applied. Solid phase treatment by WRF was also shown previously to be inefficient in removing carbamazepine (approximately 50\%) (Rodríguez-Rodrígueza et al., 2011) . However, Tran et al. (2010) observed $80 \%$ removal by $T$. versicolor, indicating the difference in performance of different WRF species, which will be further discussed in Section 4.

\subsubsection{Combined effect of EDG and EWG}

It should be noted that in the previous studies some TrOC containing both EDGs and EWGs have been reported to be readily degraded, while some other TrOC have exhibited rather poor removal (Table 1). For TrOC containing both EDGs and EWGs, the overall influence of these functional groups and particularly their opposing effects on the TrOC biodegradability is complex and would generally require extensive study involving simultaneous application of quantitative structure activity relationship and biochemical interpretation (Tadkaew et al., 2011). Nevertheless some general inferences can be drawn from the extensive body of literature that has been reviewed here.

Tetrachlorobisphenol, which is a phenolic compound (containing - $\mathrm{OH}$, a strong EDG), has been reported to be well degraded despite having $-\mathrm{Cl}$ groups (strong EWG and toxic) on the aromatic ring (Nicolucci et al., 2011). The antibacterial agent triclosan has been recently reported to be a suspected EDC. Although a chlorinated compound, triclosan has also been reported to be well degraded by laccase (Cajthaml et al., 2009a; Kurniawati \& Nicell, 2007), possibly due to the presence of EDGs representative of both ethers and phenols in its structure. Cajthaml et al. (2009a) studied several different WRF species (Pycnoporus cinnabarinus, P. chrysosporium, P. 
magnolia, Pleurotus ostreatus), most of which eliminated more than $85 \%$ triclosan at an initial concentration of $2.5 \mathrm{mg} / \mathrm{L}$.

Naproxen, which contains an ether group (EDG) and a carboxyl group (EWG), has been found to be degraded by whole-cell preparations of several fungal species, including $T$. versicolor, $B$. adusta and P. chrysosporium (Marco-Urrea et al., 2010a; Rodarte-Morales et al., 2011; Tran et al., 2010). Ibuprofen, which contains a methyl group (EDG) but also a carboxyl group, has also been reported (Marco-Urrea et al., 2009; Rodarte-Morales et al., 2011; Tran et al., 2010) to be well removed (80-100\%) by WRF at initial ibuprofen concentrations ranging from 0.01 to 10 $\mathrm{mg} / \mathrm{L}$. Furthermore, sulfonamide antibiotics such as sulfamethoxazole and sulfamethazine which possess sulfonamide (EWG) and amine (EDG) groups, have been reported to be effectively removed by WRF treatment (Accinelli et al., 2010; Rodarte-Morales et al., 2011; RodríguezRodrígueza et al., 2011). Complete removals of these compounds have been obtained for various initial concentrations ranging from 1 to $10 \mathrm{mg} / \mathrm{L}$ by different WRF species in batch tests (Rodarte-Morales et al., 2011; Rodríguez-Rodrígueza et al., 2011). Diclofenac, a biologically persistent pharmaceutical compound containing amine (EDG), carboxylic and chlorine (EWG), has been also reported to be efficiently degraded by WRF treatment (100\%) over a concentration range of 0.01 to $5 \mathrm{mg} / \mathrm{L}$ (Lloret et al., 2010; Marco-Urrea et al., 2010c; Rodarte-Morales et al., 2011; Tran et al., 2010; Yang et al., 2012a; Zhang \& Geißen, 2010).

Comparing the time required for complete removal of the above mentioned compounds, it is interesting to note that sulfamethoxazole and sulfamethazine have been reported to be fully eliminated within two weeks, while bisphenol substances have been reported to be removed within four days (Hirano et al., 2000; Rodarte-Morales et al., 2011; Rodríguez-Rodrígueza et al., 2011). Faster removal of the bisphenol compounds can be attributed to the existence of a strong EDG (-OH group) in their structure. On the other hand, depending on the fungus species and its enzyme types and applied concentration of the compounds, diclofenac required considerably longer, from a few hours (Lloret et al., 2010; Marco-Urrea et al., 2010c; Tran et al., 2010; Zhang \& Geißen, 2010) up to two weeks (Rodarte-Morales et al., 2011).

Some TrOC containing both EDG and EWG may exhibit poor removal by WRF treatment: for instance, fluoxetine (Eibes et al., 2011; Rodarte-Morales et al., 2011), clofibric acid (Marco- 
Urrea et al., 2009; Tran et al., 2010), terbuthylazine (Bending et al., 2002), metalaxyl (Bending et al., 2002), atrazine (Bending et al., 2002) and diuron (Bending et al., 2002; Torres-Duarte et al., 2009). Rodarte-Morales et al. (2011) reported that the WRF B. adusta, B. sp. and P. chrysosporium were able to eliminate fluoxetine only by 24, 44 and $18 \%$, respectively over two weeks. Eibes et al. (2011) used the commercially available versatile peroxidase from B. adusta and itonly eliminated $10 \%$ of $2.5 \mathrm{mg} / \mathrm{L}$ fluoxetine. Negligible or low removal (ranging from 0 $48 \%$ ) of clofibric acid by treatment with several WRF strains has been observed (Marco-Urrea et al., 2009). Terbuthylazine was only partially eliminated (ca. 40\%) by several species (Auricularia auricola, Agrocybe semiorbicularis, Flammulina velupites, Pleurotas ostreatus and Phanerochaete velutina) when a basal liquid nutrient solution was used as the growth medium. Four pesticides: atrazine (Bending et al., 2002), diuron (Bending et al., 2002; Torres-Duarte et al., 2009), metalaxyl (Bending et al., 2002) and methoxychlor (Hirai et al., 2004) were reported to be recalcitrant to WRF treatment ( $<50 \%$ removal). Torres-Duarte et al. (2009) explained that the reason for low removal of these halogenated pesticides was the absence of strong EDG such as phenolic or aromatic amine groups, and presence of a strong electron withdrawing group $(-\mathrm{Cl})$. However, Hai et al. (2011) observed that mixed cultures of bacteria and fungus can effectively remove $(100 \%)$ atrazine, while neither fungus nor bacteria alone could remove the compound, suggesting that bacteria and fungi adopted different but complementary metabolic pathways for this compound.

\subsection{TrOC hydrophobicity}

Studies related to bacteria-dominated activated sludge have demonstrated that hydrophobicity plays a significant role in terms of biosorption of TrOC (Suárez et al., 2008). It is interesting to note that several TrOC, which have been reported to be efficiently removed by whole-cell WRF treatment, such as bisphenol A, bisphenol B, bisphenol F, tetrachlorobisphenol A, estrone, 17 $\alpha$ ethynylestradiol, triclosan, and nonylphenol (Cajthaml et al., 2009a; Cajthaml et al., 2009b; Lee et al., 2005; Nicolucci et al., 2011; Tamagawa et al., 2005), possess significant hydrophobicity $(\log \mathrm{D}>3.2)$. As a notable omission, however, most of the available studies have mainly reported the aqueous phase removal of the TrOC without monitoring the extent of biosorption, making it difficult to assess the relative contribution of biodegradation and biosorption to the overall removal of the highly hydrophobic TrOC. Yang et al. (2012a) separately measured biosorption 
and biodegradation, and reported that although initial biosorption was evident, biodegradation was the main mechanism of aqueous phase removal of bisphenol $\mathrm{A}$ and diclofenac, which were significantly hydrophobic under the acidic $\mathrm{pH}$ tested. Interestingly, methoxychlor removal in another study (Hirai et al., 2004) was not as high as bisphenol A and diclofenac in the study of Yang et al. (2012a) although methoxychlor is significantly hydrophobic (log D is 5.07 at pH 5) (Hirai et al., 2004), which indicated that a part of methoxychlor molecule could be adsorbed onto the biomass, but the resistant structure prevented further biodegradation. On the other hand, some compounds with low log $\mathrm{D}$ have shown high rates of removal, for instance, sulfamethoxazole (Rodarte-Morales et al., 2011; Rodríguez-Rodrígueza et al., 2011), sulfamethazine (Rodríguez-Rodrígueza et al., 2011), ibuprofen (Marco-Urrea et al., 2009; Rodarte-Morales et al., 2011; Tran et al., 2010), naproxen (Marco-Urrea et al., 2010a; RodarteMorales et al., 2011; Rodarte-Morales et al., 2010; Rodríguez-Rodríguez et al., 2010b; Tran et al., 2010) and citalopram (Cabana et al., 2007b; Rodarte-Morales et al., 2011). Notably, these compounds possess amine $\left(-\mathrm{NH}_{2}-\right)$ or hydroxyl $(-\mathrm{OH})$ groups in their structure, which, based on the literature reviewed here, appear to make compounds more amenable to fungal treatment. As expected, compounds with low log D value as well as resistant structure such as carbamazepine, fluoxetine, clofibric acid and atrazine (Bending et al., 2002; Eibes et al., 2011; Marco-Urrea et al., 2009; Marco-Urrea et al., 2010d) demonstrated low and/or variable removal depending on the fungal species used. Further discussion about removal mechanisms is detailed in section 6 .

\section{Effect of fungal species}

Different WRF species have been tested for TrOC removal in the previous studies. The performance of different species for the removal of the same TrOC may vary due to the different enzyme systems harboured by different fungal species. Table 2 highlights the comparative removal data of some frequently reported TrOC by different fungal species (whole-cell) to facilitate further critical discussion.

\section{Table 2}

Several studies have investigated the TrOC removal performance of $T$. versicolor, which is also known as Coriolus versicolor (Bending et al., 2002; Okazaki et al., 2002). T. versicolor generally 
secretes three types of enzyme: laccase, $\mathrm{LiP}$ and $\mathrm{MnP}$, but laccase may be predominant in certain strains. Reported results show that with some exeptions T. versicolor can achieve high removal of all four categories of TrOC in Table 1, especially some of the resistant compounds such as carbamazepine, diuron and clofibric acid (Marco-Urrea et al., 2009; Rodarte-Morales et al., 2011; Tran et al., 2010). However, not all compounds could be efficiently removed by T. versicolor; some resistant compounds like metalaxyl were poorly removed by whole-cell treatment (Bending et al., 2002; Cajthaml et al., 2009a).

Some studies have reported the effect of growth medium or matrix on the removal efficiency. $T$. versicolor performed better in aqueous media rather than on solid matrices (RodríguezRodrígueza et al., 2011). Diclofenac, ibuprofen, and naproxen were completely removed in liquid media (Marco-Urrea et al., 2009; Tran et al., 2010), but were only partially removed (64, 75 and 47\%, respectively) in solid sludge treatment (Rodríguez-Rodrígueza et al., 2011).

It is noteworthy that data derived from different studies on the capacity of WRF for TrOC removal need to be carefully compared because the experimental conditions in those studies may have been different. However, the data compiled in Table 2 reveals, in general, better efficiency of $T$. versicolor compared with the other species tested. For example, B. adusta possesses a similar suite of enzymes as T. versicolor. However, unlike T. versicolor, B. adusta has been reported to achieve low removal of BPA and diuron (Cajthaml et al., 2009a; Torres-Duarte et al., 2009). Some compounds such as carbamazepine (Tran et al., 2010), atrazine (Bending et al., 2002), diuron (Bending et al., 2002), terbuthylazine (Bending et al., 2002) and clofibric acid (Marco-Urrea et al., 2010c), which were resistant to other species, were significantly (over 60\%) removed by $T$. versicolor. Marco-Urrea et al (2009) reported over $80 \%$ removal of clofibric acid from a solution of $10 \mathrm{mg} / \mathrm{L}$ by $T$. versicolor (ATCC 42530) compared to only $45 \%$ or less achieved by $P$. chrysosporium. Tran et al. (2010) observed high removal of carbamazepine ( $80 \%$ ) by $T$. versicolor, while other species such as I. lacteus and P. chrysosporium only achieved less than 50\% removal (Marco-Urrea et al., 2009). T. versicolor showed significantly better removal of atrazine, diuron and terbuthylazine (over 60\%) (Bending et al., 2002) compared to that $(<40 \%)$ by other species (Dichotomitus squalens and P. velutina) (Bending et al., 2002; Torres-Duarte et al., 2009), which may suggest synergistic action of the three enzymes for $T$. versicolor. 


\section{TrOC removal by extracellular LME}

\subsection{Effect of enzyme types}

In addition to whole-cell WRF, removal of TrOC has been investigated either by employing crude culture extract (Tran et al., 2010) or by purified enzymes (Kim \& Nicell, 2006a). In order to facilitate critical comparison, Table 3 summarises the available information regarding $\mathrm{TrOC}$ removal via treatment by different individual fungal enzymes.

\section{Table 3}

Studies involving the application of purified or commercial laccase solutions reveal that it can efficiently degrade phenolic structures such as bisphenol A, triclosan, nonylphenol, estrone, and 17 $\alpha$-ethynylestradiol (Auriol et al., 2008; Auriol et al., 2007; Cabana et al., 2007b; Fukuda et al., 2001; Saito et al., 2004). However, some complex structures like carbamazepine and clofibric acid are resistant to laccase (Tran et al., 2010). LiP preparations from P. chrysosporium was reported to remove diclofenac efficiently (Zhang \& Geißen, 2010), while other compounds, namely bisphenol A (Wang et al., 2012) and 17ß-estradiol (Mao et al., 2010) which are amenable to laccase treatment, are not greatly removed by LiP. MnP solution could degrade similar TrOC as does laccase, for example, phenolic compounds (such as bisphenol A) (Lee et al., 2005; Tsutsumi et al., 2001), and hormones (such as 17 $\beta$-estradiol, $17 \alpha$-ethynylestradiol, genistein and estrone) (Auriol et al., 2007; Suzuki et al., 2003; Tamagawa et al., 2005). Furthermore, MnP demonstrated greater ability for methoxychlor degradation (69\%) than laccase and LiP (23-28\%) (Hirai et al., 2004). Horseradish peroxidase was also reported to remove estrogens, including 17 $\beta$-estradiol, estriol and 17 $\alpha$-ethynylestradiol (Auriol et al., 2008).

\subsection{Effect of addition of redox mediators}

Mediators are low molecular weight compounds that act as an 'electron shuttle' between the oxidizing enzyme and the target compounds, enabling a greater range of compounds to be degraded by laccase and improving the degree of oxidation of compounds. Several studies have demonstrated the enhancement of TrOC removal by the addition or presence of mediators. Naproxen (Marco-Urrea et al., 2010a; Rodríguez-Rodríguez et al., 2010a) and triclosan (Kim \& Nicell, 2006b) were removed only by $10 \%$ and $50 \%$, respectively, by a laccase preparation, 
however, the addition of 1-hydroxybenzotriazole (HBT) improved the removal to 95\% (MarcoUrrea et al., 2010a) and 90\% (Murugesan et al., 2010), respectively. The presence of Tween 80 as a mediator in the test solution helped increase the removal from 0 to $65 \%$ when $10 \mathrm{mM}$ methoxychlor was treated by MnP solution (Hirai et al., 2004). Lloret et al. (2010) observed improvement in the removal efficiency of diclofenac and estrone (from $\sim 65 \%$ to $95 \%$ and from $64 \%$ to $82 \%$, respectively) in the presence of HBT. In comparison to negligible removal by laccase-only treatment, Hata et al.(2010b) reported 22\% removal of carbamazepine by an HBTmediated laccase systemhowever, they noted over $90 \%$ decrease of laccase activity within only 8 h. By repeatedly adding both laccase and HBT to the reaction mixture every $8 \mathrm{~h}$, they achieved 60\% removal within $48 \mathrm{~h}$ (Hata et al., 2010b).

The capacity of a certain mediator to improve degradation is compound-specific. For instance, in the case of triclosan, addition of syringaldehyde or (2,2,6,6-tetramethylpiperidin-1-yl)oxyl to the laccase solution derived from a $T$. versicolor culture resulted in inferior performance than with no mediator present (Kim \& Nicell, 2006b). By contrast, syringaldehyde was more effective in enhancing the degradation of sulfamethoxazole than HBT (Yang, 2012b). Weng et al. (2012) tested six different mediators and reported higher removal of sulfadimethoxine and sulfamonomethoxine by the laccase-violuric acid solution which exhibited the highest redox potential. Insignificant improvement after addition of some mediators (e.g., veratryl alcohol and 2,2'-azinobis(3-ethylbenzthiazoline-6-sulfonate)) on the removal of certain resistant compounds, such as carbamazepine (Tran et al., 2010; Zhang \& Geißen, 2010) and clofibric acid (Tran et al., 2010), and others readily amenable to laccase degradation, such as diclofenac (Tran et al., 2010; Zhang \& Geißen, 2010), estrone (Auriol et al., 2008; Lloret et al., 2010) and 17ß-estradiol (Auriol et al., 2008; Lloret et al., 2010; Suzuki et al., 2003) has been observed; however, HBT was reported to positively affect the removal efficiency of most of these compounds by laccase. It is interesting to note that removal efficiency improvement of $17 \beta$-estradiol by addition of HBT only occurred when the laccase activity of the test medium was low (less than $20 \mathrm{U} / \mathrm{mL}$ ) (Auriol et al., 2007); there was no difference in removal when laccase activity reached $20 \mathrm{U} / \mathrm{mL}$.

\subsection{Effect of immobilization of enzyme}


Immobilization of LME on solid supports aims to enhance its potential for industrial use through repeated utilization (Cabana et al., 2007b). Immobilization generally results in enzyme stabilization against thermal and chemical denaturation and in kinetic behaviour modifications. The approaches to LME immobilization include chemical methods and physical methods. Chemical methods mainly include: (1) enzyme attachment to the matrix by covalent bonds, and (2) enzyme cross-linking by multifunctional reagents (Cabana et al., 2009; Cabana et al., 2007c). Physical methods involve entrapment of enzyme molecules within a porous hollow fiber, in spun fibers within an insoluble gel matrix and/or enzyme entrapment within a reverse micelle.

\section{Table 4}

Table 4 highlights TrOC removal efficiencies by LME after different immobilization methods. A direct comparison of the performance of different carriers or immobilization techniques based on Table 4 may not always be valid because different enzymes from different WRFs were used in these studies. Nevertheless, some interesting observations regarding compound-specific performance of the options can be made. For instance, in previous studies utilising free laccase, bisphenol A (Cabana et al., 2007a; Fukuda et al., 2001; Okazaki et al., 2002), nonylphenol (Okazaki et al., 2002) and triclosan (Kurniawati \& Nicell, 2007; Okazaki et al., 2002) were generally removed with high efficiency; however, when laccase was immobilized in order to increase stability and allow repeated use, in some cases, lower TrOC removal efficiency was observed. For example, while high removal (80-95\%) of both bisphenol A and nonylphenol was achieved by cross-linked laccase (Cabana et al., 2007c) or versatile peroxidase (Taboada-Puig et al., 2011) aggregates prepared using polyethylene glycol, the removal of triclosan by crosslinked versatile peroxidase was only $25 \%$. On the other hand, only $40-50 \%$ removal of nonylphenol and triclosan was achieved by laccase immobilized in silica beads (Songulashvili et al., 2012) (Table 4). Immobilization of laccase or versatile peroxidase resulted relatively efficient removal of hormones, e.g., estrone ( 65\%), 17 $\beta$-estradiol $(65-80 \%)$ and $17 \alpha$ ethynylestradiol (80-90\%) (Cardinal-Watkins \& Nicell, 2011; Lloret et al., 2011; Lloret et al., 2010; Lloret et al., 2012; Taboada-Puig et al., 2011). Enzymatic activity may significantly decrease following the random immobilization of the enzyme molecules on the support due to different orientations of the molecules with respect to the support or due to multiple point attachment. Nevertheless, because immobilization can make the enzymes more stable and enable 
their reuse, it is important to investigate better ways of enzyme immobilization for larger scale operations.

\section{Effect of physicochemical properties of wastewater matrix}

With a few exceptions (e.g. (Auriol et al., 2007)) most of the WRF studies to date have been conducted with synthetic wastewater. Apart from the factors discussed in the previous sections, TrOC removal performance of whole-cell WRF or their LME can also depend on the different physicochemical properties of the synthetic wastewater, namely, $\mathrm{pH}$, temperature, salinity, and the presence of metal or other inhibitors. For example, Zhang and Geißen (Zhang \& Geißen, 2010) reported that diclofenac was completely degraded by LiP in the $\mathrm{pH}$ range of 3.0-4.5. However, diclofenac degradation efficiency significantly decreased from $100 \%$ at $\mathrm{pH} 4.5$ to $10 \%$ at $\mathrm{pH} 6.0$ due to the inactivation of LiP at higher $\mathrm{pH}$ (Zhang \& Geißen, 2010). A pH of 6 was reported as the optimum $\mathrm{pH}$ for laccase-catalyzed treatment of estrogens (Auriol et al., 2007) and bisphenol A (Fukuda et al., 2001). A pH of 5 appeared to be the optimum for the degradation of triclosan by laccase form T. versicolor (Kim \& Nicell, 2006b), while the optimal pH for laccase to degrade chlorophenols was around 5.5 (Zhang et al., 2008). The optimal temperature for LME activity may differ greatly from one strain to another. However, $25-30{ }^{\circ} \mathrm{C}$ and $37-40{ }^{\circ} \mathrm{C}$ are usually reported as the optimum temperature for laccase and the peroxidases, respectively, although thermostable LME showing stable performance at over $50{ }^{\circ} \mathrm{C}$ has also been reported (Cabana et al., 2007b; Kim \& Nicell, 2006a; Soares et al., 2006).

As noted earlier, the effect of wastewater matrix on TrOC removal has been investigated in only a few studies. Wastewater matrix constituents did not have a significant impact on the laccasecatalyzed treatment for the conversion of steroid estrogens in a study by Auriol et al. (2007). Specifically, compared with the synthetic wastewater, similar removal of estrogens could be accomplished from real municipal wastewater with similar laccase dosage (Auriol et al., 2007). However, Mao et al. (2010) found that while the presence of veratryl alcohol enhanced the catalytic performance of LiP, such enhancement was inhibited in the presence of natural organic matter. Kim and Nicell (2006b) studied the effect of dissolved wastewater constituents including various inorganic salts, organic compounds and heavy metal ions on bisphenol A degradation by 
laccase. Bisphenol A conversion was inhibited in the presence of anions such as sulfite, thiosulfate, sulfide, nitrite and cyanide. The metal ions (Fe(III) and $\mathrm{Cu}(\mathrm{II})$ ) and the halogens (chloride and fluoride) substantially suppressed the conversion of bisphenol A.

\section{Removal mechanisms and degradation pathways}

\subsection{Removal mechanisms}

During TrOC removal by a whole-cell preparation, sorption to the fungal mycelium may be the first essential step for biodegradation catalysed by intracellular, mycelium-bound or extracellular enzymes (Yang, 2012b). On the other hand, in vitro tests employing crude or purified enzyme solutions reveal the capacity of selected enzymes to catalyse TrOC biodegradation in absence of sorption to fungal mycelium. A batch test study by Yang (2012b) with live and inactivated WRF cultures, and crude enzyme extract, revealed high removal of significantly hydrophobic compounds $(\log \mathrm{D} \geq 4)$ by all three options, confirming that the significantly hydrophobic compounds were in fact biodegraded, not only biosorbed. Some studies have reported comparable removal via both whole-cell and extracellular enzyme solution treatment of compounds such as bisphenol A (Cabana et al., 2007a; Cajthaml et al., 2009a; Fukuda et al., 2001; Kim \& Nicell, 2006a; Lee et al., 2005; Nicolucci et al., 2011; Tsutsumi et al., 2001), triclosan (Cajthaml et al., 2009a; Kurniawati \& Nicell, 2007), estrone (Auriol et al., 2008; Auriol et al., 2007) and 17 $\alpha$-ethynylestradiol (Auriol et al., 2008; Auriol et al., 2007; Suzuki et al., 2003) (Figure 1).

\section{Figure 1}

Extracellular enzyme preparations may not always achieve a removal similar to whole-cell WRF. For example, the resistant compound carbamazepine was removed to a high degree by a few fungal species including T. versicolor ATCC 42530 (76\%) (Tran et al., 2010) and Pleurotus ostreatus (100\%) (Golan-Rozen et al., 2011). By contrast, crude laccase solution could achieve only 5-15\% biodegradation (Golan-Rozen et al., 2011; Tran et al., 2010). Hydrophilic compounds, such as naproxen ( $\log \mathrm{D}=2.82$ ) (Rodarte-Morales et al., 2011; Tran et al., 2010) and ibuprofen ( $\log \mathrm{D}=3.36)$ (Marco-Urrea et al., 2009; Rodarte-Morales et al., 2011; Rodarte- 
Morales et al., 2010; Tran et al., 2010) were completely removed by whole-cell fungal treatment. However, there are no reports in the literature of similar levels of removal of these compounds by crude or extracellular enzyme solutions. For example, degradation of naproxen was less than 10\% with a purified laccase solution (Lloret et al., 2010; Marco-Urrea et al., 2010a). Ibuprofen was removed at 37.5 - 50\% levels by a commercial laccase solution (Tran et al., 2010), while the application of crude fungal enzyme (laccase and MnP) only achieved 12.5-15\% removal. Because naproxen and ibuprofen are hydrophilic and therefore subject to only limited biosorption, this observation points to the role of intracellular and/or mycelium-associated enzymes in TrOC biodegradation. The role of intracellular enzymes has been demonstrated more clearly by observing the removal efficiency following selective inhibition of cytochrome P450 activity (Figure 1). A noticeable inhibition of naproxen degradation was observed when the cytochrome P450 inhibitor 1-aminobenzotriazole was added to the fungal cultures (Marco-Urrea et al., 2010a). Golan-Rozen et al. (2011) found that cytochrome P450 played a significant role in carbamazepine removal: a cytochrome P450-inhibited culture could achieve only 15\% removal, while in the absence of the inhibitor the removal improved to $100 \%$. A similar observation was be made by Hata et al. (2010a) who reported that diclofenac removal by $P$. sordida decreased from complete removal to $60 \%$ following addition of cytochrome P450 inhibitor to the test solution. Experiments with purified laccase and mediator-enhanced laccase preparations resulted in almost complete removal of sulfamethazine; on the other hand, inhibition of sulfamethazine degradation was observed when piperonyl butoxide, a cytochrome P450 inhibitor, was added to the fungal cultures(Garcia-Galan et al., 2011).

Before drawing any firm conclusions based on Figure 1, due consideration needs to be given tothe fact that Figure 1 is based on data compiled from a number of independent studies which may not have been conducted under the same conditions. Nevertheless, Figure 1 indicates that compared with enzymatic treatment, whole-cell WRF treatment is applicable to a wider spectrum of TrOC, possibly because of the synergistic effect of intracellular, mycelium-bound and extracellular enzymes as well as due to sorption of TrOC on the biomass.

\subsection{Degradation pathways}


In the majority of studies, the focus was predominantly in relation to the disappearance of the parent compound. Only a limited amount of literature is available on degradation pathways and the intermediate breakdown products. For example, hydroxy diclofenac is formed as an intermediate product during diclofenac degradation, indicating that an electron donating group (hydroxyl group) is first transferred to the compound to make it amenable to further biodegradation (Hata et al., 2010a; Marco-Urrea et al., 2010c). In vivo and in vitro experiments using the cytochrome P450 inhibitor 1-aminobenzotriazole and purified laccase, respectively, suggested that at least two different mechanisms are employed by $T$. versicolor to initiate diclofenac degradation (Marco-Urrea et al., 2010c). While hydroxylated metabolites were identified as degradation intermediates in fungal cultures spiked with diclofenac, laccasecatalyzed transformation of diclofenac led to the formation of 4-(2,6 dichlorophenylamino)-1,3benzenedimethanol, which was not detected in in vivo experiments probably due to the low laccase activity levels observed during the first hours of incubation (Marco-Urrea et al., 2010c). Both parent compound and intermediates disappeared after $24 \mathrm{~h}$, leading to a decrease in ecotoxicity of the treated liquid. Hata et al. (2010a) reported that, similar to diclofenac, cytochrome P450-catalyzed hydroxylation may also be involved in the elimination and detoxification of mefenamic acid by $P$. sordida (YK-624). The cytochrome P450 system was also reported to catalyze the first step of ketoprofen degradation, yielding (2-[3-(4hydroxybenzoyl)phenyl]-propanoic acid) by hydroxylation of the aromatic ring, and (2-[(3hydroxy(phenyl)methyl)phenyl]-propanoic acid) by reduction of the ketone group, and the ligninolytic enzyme system (laccase) appeared to play a minor role in ketoprofen degradation (Marco-Urrea et al., 2010b).

Different pathways were observed during naproxen degradation by WRF treatment. P450mediated desmethylation led to formation of 6-desmethylnaproxen (Marco-Urrea et al., 2010a; Rodarte-Morales et al., 2012b), while a second metabolite 1-(6-methoxynaphthalen-2yl)ethanone) appeared to have been formed via laccase catalysis (Marco-Urrea et al., 2010a). After $6 \mathrm{~h}$ of incubation, both parent compound and the intermediates disappeared from the medium, and it was confirmed that the treated medium was not toxic (Marco-Urrea et al., 2010a).

Hydroxylation at the primary carbon to form the hydroxy-ibuprofen is the predominant initial degradation pathway for ibuprofen. Marco-Urrea et al. (2009) studied the degradation of 
ibuprofen by $T$. versicolor and reported that it was first transformed to 1-hydroxy ibuprofen and 2-hydroxy ibuprofen via oxidation of its isopropyl chain. These byproducts were subsequently degraded by the fungus to 1,2-dihydroxy ibuprofen, which accumulated over the incubation period (7 d). Notably, the ecotoxicity of the treated medium containing 1,2-dihydroxy ibuprofen was higher than the initial solution, although still lower than that set for wastewater discharge in industrial areas. The authors (Marco-Urrea et al., 2009), however, emphasized that the ibuprofen concentration used in their experiments $(10 \mathrm{mg} / \mathrm{L})$ was several orders of magnitude higher than the concentrations found in the aquatic environment, and advised caution in extrapolating their data.

Acridone, acridine, 10,11-dihydro-10,11-dihydroxy-carbamazepine, and 10,11-epoxycarbamazepine were identified as major, stable metabolites following treatment of carbamazepine by the whole-cell culture of T. versicolor. Acute toxicity tests showed that the final effluents from the reactors were not toxic (Jelic et al., 2012). Golan-Rozen et al. (2011) reported that two families of enzymes, namely, extracellular MnP (in a $\mathrm{Mn}^{2+}$-dependent or independent manner) and intracellular P450, are involved in the oxidation of carbamazepine by the whole-cell culture of Pleurotus ostreatus. They observed that 10,11-epoxycarbamazepine was the major stable metabolite when the initial carbamazepine concentration was $10 \mathrm{mg} / \mathrm{L}$; however, at an environmentally relevant concentration $(1 \mu \mathrm{g} / \mathrm{L})$, Pleurotus ostreatus can continue degradation of 10,11-epoxycarbamazepine to 10,11 trans-diol, which could be bioavailable to other microorganisms (Golan-Rozen et al., 2011), potentially leading to mineralization. On the other hand, two degradation products, namely, 10,11-dihydro-10,11epoxycarbamazepine and $9(10 \mathrm{H})$-acridone, were formed via repeated treatment with laccase from T. versicolor and HBT (Hata et al., 2010b). Eibes et al. (2011) identified a metabolite, namely 3-amino-5-methylisoxazole, during treatment of sulfamethoxazole with versatile peroxidase from the ligninolytic fungus B. adusta.

\section{Future scope of research}

This review critically analyses the available literature on the application of WRF and their enzyme systems for efficient removal of a wide range of resistant TrOC in pure culture batch tests under sterile conditions. In contrast to the significant number of reports demonstrating the 
excellent capacity of WRF to degrade persistent TrOCs in small-scale, sterile batch tests, far fewer studies have been conducted in continuous reactors. There are several inherent limitations of continuous fungus reactors, especially under non-sterile operating conditions. As WRF are eukaryotes and grow more slowly than prokaryotic bacteria, the bacteria can outperform fungi in the competition for substrate (Hai et al., 2009; Libra et al., 2003). Thus competition for substrate with bacteria, and bacterial colonization and damage of fungal mycelium is the primary problem reported (Hai et al., 2009; Libra et al., 2003), as it leads to gradual loss of fungal enzymatic activity. Another limitation of continuous fungal reactors is the loss of enzymes and mediators along with treated effluent (Hai et al., 2012; Hai et al., 2008).

In good agreement with the studies of other groups of resistant compounds, the few available studies on TrOC removal by WRF also report somewhat poorer removal by fungal reactors operated in non-sterile conditions and/or in continuous flow mode(Jelic et al., 2012; RodarteMorales et al., 2012a; Zhang \& Geißen, 2012). Rodarte-Morales et al. (2012a) reported decreased removal of anti-inflammatory drugs due to change in the operation mode of a fungal reactor from fed-batch to continuous flow. By applying an HRT of 3 days, Jelic et al. (2012) obtained up to $54 \%$ removal of carbamazepine by a fluidized bed bioreactor. Zhang and Geißen (2012) reported a 60\% removal of carbamazepine by an attached growth (on porous polyether foam) fungal reactor treating non-sterile real sewage treatment plant effluent. In a recent study by Yang et al. (2012b) the performance of a continuous flow fungal membrane bioreactor was dependent on TrOC loading. At an HRT of two days and TrOC loadings of $475 \pm 25$ (bisphenol A) and $345 \pm 112$ (diclofenac) $\mu \mathrm{g} / \mathrm{L} . \mathrm{d}, 80-90 \%$ removal of bisphenol A and approximately 55\% removal of diclofenac were achieved. Compared with the excellent TrOC removal performance in pure fungal batch tests, the presence of bacteria in the membrane bioreactor led to the following two distinct observations: (i) higher removal of total organic carbon which was mainly composed of easily biodegradable malt, and (ii) reduced removal of diclofenac (Yang, 2012b). It is, therefore, evident that more systematic studies on the enhancement of fungal degradation of $\mathrm{TrOC}$ in continuous reactors in non-sterile environments are necessary. 


\section{Conclusion}

Trace organic contaminants (TrOC) bearing strong electron donating groups (e.g., hydroxyl and amines) are well removed by WRF, while compounds with electron withdrawing groups (e.g. halogen, nitro, azepine and triazine) are biodegraded mainly by WRF secreting all three major LME. Whole-cell WRF appear to effectively treat a wider spectrum of TrOC than crude culture supernatants or purified enzymes, possibly because of the complementary and/or synergistic effect of mycelium-bound and intracellular enzymes as well as biosorption of the TrOC. Depending on the initial concentration of TrOC, WRF species and associated LME, addition of redox mediators can improve the removal of the problematic compounds.

\section{ACKNOWLEDGMENT}

Dr. Faisal I. Hai acknowledges research grants from the University Research Committee and GeoQuEST Research Centre of University of Wollongong, Australia to carry out this work.

\section{References}

[1] Accinelli, C., Saccà, M.L., Batisson, I., Fick, J., Mencarelli, M., Grabic, R. 2010. Removal of oseltamivir (Tamiflu) and other selected pharmaceuticals from wastewater using a granular bioplastic formulation entrapping propagules of Phanerochaete chrysosporium. Chemosphere, 81, 436443.

[2] Alexander, J.T., Hai, F.I., Al-aboud, T.M. 2012. Chemical coagulation-based processes for trace organic contaminant removal: Current state and future potential. Journal of Environmental Management, 111, 195-207.

[3] Auriol, M., Filali-Meknassi, Y., Adams, C.D., Tyagi, R.D., Noguerol, T.N., Pina, B. 2008. Removal of estrogenic activity of natural and synthetic hormones from a municipal wastewater: Efficiency of horseradish peroxidase and laccase from Trametes versicolor. Chemosphere, 70, 445-452.

[4] Auriol, M., Filali-Meknassi, Y., Tyagi, R.D., Adams, C.D. 2007. Laccase-catalyzed conversion of natural and synthetic hormones from a municipal wastewater. Water Research, 41, 3281-3288.

[5] Bending, G.D., Friloux, M., Walker, A. 2002. Degradation of contrasting pesticides by white rot fungi and its relationship with ligninolytic potential. FEMS Microbiology Letters, 212, 59-63.

[6] Cabana, H., Alexandre, C., Agathos, S.N., Jones, J.P. 2009. Immobilization of laccase from the white rot fungus Coriolopsis polyzona and use of the immobilized biocatalyst for the continuous elimination of endocrine disrupting chemicals. Bioresource Technology, 100, 3447-3458.

[7] Cabana, H., Jiwan, J.-L.H., Rozenberg, R., Elisashvili, V., Penninckx, M., Agathos, S.N., Jones, J.P. $2007 a$. Elimination of endocrine disrupting chemicals nonylphenol and bisphenol $A$ and personal care product ingredient triclosan using enzyme preparation from the white rot fungus Coriolopsis polyzona. Chemosphere, 67, 770-778.

[8] Cabana, H., Jones, J.P., Agathos, S.N. 2007b. Elimination of Endocrine Disrupting Chemicals using White Rot Fungi and their Lignin Modifying Enzymes: A Review. Engineering in Life Sciences, 7, 429-456. 
[9] Cabana, H., Jones, J.P., Agathos, S.N. 2007c. Preparation and characterization of cross-linked laccase aggregates and their application to the elimination of endocrine disrupting chemicals. Journal of Biotechnology, 132, 23-31.

[10] Cajthaml, T., Křesinová, Z., Svobodová, K., Möder, M. 2009a. Biodegradation of endocrinedisrupting compounds and suppression of estrogenic activity by ligninolytic fungi. Chemosphere, 75, 745-750.

[11] Cajthaml, T., Kresinová, Z., Svobodová, K., Sigler, K., Rezanka, T. 2009b. Microbial transformation of synthetic estrogen 17 $\alpha$-ethinylestradiol. Environmental Pollution, 157, 3325-3335.

[12] Cardinal-Watkins, C., Nicell, A.J. 2011. Enzyme-catalyzed oxidation of $17 \beta$-estradiol using immobilized laccase from Trametes versicolor. Enzyme research, 2011, 1-11.

[13] Eibes, G., Debernardi, G., Feijoo, G., Moreira, M., Lema, J. 2011. Oxidation of pharmaceutically active compounds by a ligninolytic fungal peroxidase. Biodegradation, 22, 539-550.

[14] Fukuda, T., Uchida, H., Takashima, Y., Uwajima, T., Kawabata, T., Suzuki, M. 2001. Degradation of bisphenol a by purified laccase from Trametes villosa. Biochemical and biophysical research communications, 284, 704-706.

[15] Garcia-Galan, M.J., Rodriguez-Rodriguez, C.E., Vicent, T., Caminal, G., Diaz-Cruz, M.S., Barcelo, D. 2011. Biodegradation of sulfamethazine by Trametes versicolor: Removal from sewage sludge and identification of intermediate products by UPLCâ€"QqTOF-MS. Science of The Total Environment, 409, 5505-5512.

[16] Golan-Rozen, N., Chefetz, B., Ben-Ari, J., Geva, J., Hadar, Y. 2011. Transformation of the Recalcitrant Pharmaceutical Compound Carbamazepine by Pleurotus ostreatus: Role of Cytochrome P450 Monooxygenase and Manganese Peroxidase. Environmental Science \& Technology, 45, 68006805.

[17] Hai, F.I., Modin, O., Yamamoto, K., Fukushi, K., Nakajima, F., Nghiem, L.D. 2011. Pesticide removal by a mixed culture of bacteria and white-rot fungi. Journal of the Taiwan Institute of Chemical Engineers.

[18] Hai, F.I., Nghiem, L.D., Khan, S.J., Price, W.E., Yamamoto, K. 2012 Wastewater reuse: Removal of emerging trace organic contaminants. in: Membrane Biological Reactors, (Eds.) F.I. Hai, K. Yamamoto, C.-H. Lee, IWA publishing. London (ISBN: 9781780400655, accepted Oct 2012).

[19] Hai, F.I., Yamamoto, K., Fukushi, K. 2007. Hybrid Treatment Systems for Dye Wastewater. Critical Reviews in Environmental Science and Technology, 37, 315-377.

[20] Hai, F.I., Yamamoto, K., Nakajima, F., Fukushi, K. 2012. Application of a GAC-coated hollow fiber module to couple enzymatic degradation of dye on membrane to whole cell biodegradation within a membrane bioreactor. Journal of Membrane Science, 389, 67-75.

[21] Hai, F.I., Yamamoto, K., Nakajima, F., Fukushi, K. 2009. Factors governing performance of continuous fungal reactor during non-sterile operation - The case of a membrane bioreactor treating textile wastewater. Chemosphere, 74, 810-817.

[22] Hai, F.I., Yamamoto, K., Nakajima, F., Fukushi, K. 2008. Removal of structurally different dyes in submerged membrane fungi reactor-Biosorption/PAC-adsorption, membrane retention and biodegradation. Journal of Membrane Science, 325, 395-403.

[23] Hata, T., Kawai, S., Okamura, H., Nishida, T. 2010a. Removal of diclofenac and mefenamic acid by the white rot fungus Phanerochaete sordida YK-624 and identification of their metabolites after fungal transformation. Biodegradation, 21, 681-9.

[24] Hata, T., Shintate, H., Kawai, S., Okamura, H., Nishida, T. 2010b. Elimination of carbamazepine by repeated treatment with laccase in the presence of 1-hydroxybenzotriazole. Journal of Hazardous Materials, 181, 1175-1178. 
[25] Hirai, H., Nakanishi, S., Nishida, T. 2004. Oxidative dechlorination of methoxychlor by ligninolytic enzymes from white-rot fungi. Chemosphere, 55, 641-645.

[26] Hirano, T., Honda, Y., Watanabe, T., Kuwahara, M. 2000. Degradation of Bisphenol A by the LigninDegrading Enzyme, Manganese Peroxidase, Produced by the White-rot Basidiomycete, Pleurotus ostreatus. Bioscience, Biotechnology, and Biochemistry, 64, 1958-1962.

[27] Jelic, A., Cruz-Morato, C., Marco-Urrea, E., Sarra, M., Perez, S., Vicent, T., Petrovic, M., Barcelo, D. 2012. Degradation of carbamazepine by Trametes versicolor in an air pulsed fluidized bed bioreactor and identification of intermediates. Water Research, 46, 955-964.

[28] Jones, O.A., Lester, J.N., Voulvoulis, N. 2005. Pharmaceuticals: a threat to drinking water? Trends in Biotechnology, 23, 163-167.

[29] Junghanns, C., Moeder, M., Krauss, G., Martin, C., Schlosser, D. 2005. Degradation of the xenoestrogen nonylphenol by aquatic fungi and their laccases. Microbiology, 151, 45-57.

[30] Karam, J., Nicell, J.A. 1997. Potential Applications of Enzymes in Waste Treatment. Journal of Chemical Technology \& Biotechnology, 69, 141-153.

[31] Kim, Y.-J., Nicell, J.A. 2006a. Impact of reaction conditions on the laccase-catalyzed conversion of bisphenol A. Bioresource Technology, 97, 1431-1442.

[32] Kim, Y.-J., Nicell, J.A. 2006b. Laccase catalysed oxidation of aqueous triclosan. Journal of Chemical Technology \& Biotechnology, 81, 1344-1352.

[33] Kurniawati, S., Nicell, J.A. 2007. Efficacy of mediators for enhancing the laccase-catalyzed oxidation of aqueous phenol. Enzyme and Microbial Technology, 41, 353-361.

[34] Lee, S.-M., Koo, B.-W., Choi, J.-W., Choi, D.-H., An, B.-S., Jeung, E.-B., Choi, I.-G. 2005. Degradation of Bisphenol A by White Rot Fungi, Stereum hirsutum and Heterobasidium insulare, and Reduction of Its Estrogenic Activity. Biological \& Pharmaceutical Bulletin, 28, 7.

[35] Lee, S.-M., Koo, B.-W., Lee, S.-S., Kim, M.-K., Choi, D.-H., Hong, E.-J., Jeung, E.-B., Choi, I.-G. 2004. Biodegradation of dibutylphthalate by white rot fungi and evaluation on its estrogenic activity. Enzyme and Microbial Technology, 35, 417-423.

[36] Libra, J.A., Borchert, M., Banit, S. 2003. Competition strategies for the decolorization of a textilereactive dye with the white-rot fungi Trametes versicolor under non-sterile conditions. Biotechnology and Bioengineering, 82, 736-744.

[37] Lloret, L., Eibes, G., Feijoo, G., Moreira, M.T., Lema, J.M., Hollmann, F. 2011. Immobilization of laccase by encapsulation in a sol-gel matrix and its characterization and use for the removal of estrogens. Biotechnology Progress, 27, 1570-1579.

[38] Lloret, L., Eibes, G., Lu-Chau, T.A., Moreira, M.T., Feijoo, G., Lema, J.M. 2010. Laccase-catalyzed degradation of anti-inflammatories and estrogens. Biochemical Engineering Journal, 51, 124-131.

[39] Lloret, L., Hollmann, F., Eibes, G., Feijoo, G., Moreira, M.T., Lema, J.M. 2012. Immobilisation of laccase on Eupergit supports and its application for the removal of endocrine disrupting chemicals in a packed-bed reactor. Biodegradation, 23, 373-386.

[40] Mao, L., Lu, J., Habteselassie, M., Luo, Q., Gao, S., Cabrera, M., Huang, Q. 2010. Ligninase-Mediated Removal of Natural and Synthetic Estrogens from Water: II. Reactions of $17 \beta$-Estradiol. Environmental Science \& Technology, 44, 2599-2604.

[41] Marco-Urrea, E., Pérez-Trujillo, M., Blánquez, P., Vicent, T., Caminal, G. 2010a. Biodegradation of the analgesic naproxen by Trametes versicolor and identification of intermediates using HPLCDAD-MS and NMR. Bioresource Technology, 101, 2159-2166.

[42] Marco-Urrea, E., Perez-Trujillo, M., Cruz-Morato, C., Caminal, G., Vicent, T. 2010b. White-rot fungus-mediated degradation of the analgesic ketoprofen and identification of intermediates by HPLC-DAD-MS and NMR. Chemosphere, 78, 474-481. 
[43] Marco-Urrea, E., Pérez-Trujillo, M., Cruz-Morató, C., Caminal, G., Vicent, T. 2010c. Degradation of the drug sodium diclofenac by Trametes versicolor pellets and identification of some intermediates by NMR. Journal of Hazardous Materials, 176, 836-842.

[44] Marco-Urrea, E., Pérez-Trujillo, M., Vicent, T., Caminal, G. 2009. Ability of white-rot fungi to remove selected pharmaceuticals and identification of degradation products of ibuprofen by Trametes versicolor. Chemosphere, 74, 765-772.

[45] Marco-Urrea, E., Radjenovic, J., Caminal, G., Petrovic, M., Vicent, T., Barceló, D. 2010d. Oxidation of atenolol, propranolol, carbamazepine and clofibric acid by a biological Fenton-like system mediated by the white-rot fungus Trametes versicolor. Water Research, 44, 521-532.

[46] Mayer, A.M., Staples, R.C. 2002. Laccase: new functions for an old enzyme. Phytochemistry, 60, 551-565.

[47] Murugesan, K., Chang, Y.-Y., Kim, Y.-M., Jeon, J.-R., Kim, E.-J., Chang, Y.-S. 2010. Enhanced transformation of triclosan by laccase in the presence of redox mediators. Water Research, 44, 298-308.

[48] Nicolucci, C., Rossi, S., Menale, C., Godjevargova, T., Ivanov, Y., Bianco, M., Mita, L., Bencivenga, U., Mita, D., Diano, N. 2011. Biodegradation of bisphenols with immobilized laccase or tyrosinase on polyacrylonitrile beads. Biodegradation, 1-11.

[49] Okazaki, S.-y., Michizoe, J., Goto, M., Furusaki, S., Wariishi, H., Tanaka, H. 2002. Oxidation of bisphenol A catalyzed by laccase hosted in reversed micelles in organic media. Enzyme and Microbial Technology, 31, 227-232.

[50] Reddy, C.A. 1995. The potential for white-rot fungi in the treatment of pollutants. Current Opinion in Biotechnology, 6, 320-328.

[51] Rodarte-Morales, A., Feijoo, G., Moreira, M., Lema, J. 2011. Degradation of selected pharmaceutical and personal care products (PPCPs) by white-rot fungi. World Journal of Microbiology and Biotechnology, 27, 1839-1846.

[52] Rodarte-Morales, A.I., Feijoo, G., Moreira, M.T., Lema, J. 2012a. Evaluation of two operational regimes fed-batch and continuous for the removal of pharmaceuticals in a fungal stirred tank reactor. Chemical engineering transactions, 27, 151-156.

[53] Rodarte-Morales, A.I., Feijoo, G., Moreira, M.T., Lema, J.M. 2012b. Operation of stirred tank reactors (STRs) and fixed-bed reactors (FBRs) with free and immobilized Phanerochaete chrysosporium for the continuous removal of pharmaceutical compounds. Biochemical Engineering Journal, 66, 38-45.

[54] Rodarte-Morales, A.I., Moreira, M.T., Feijoo, G., Lema, J.M. 2010. Evaluation of two fungal strains for the degradation of pharmaceutical and personal care products (PPCPs). Chemical Engineering Transactions, 20, 31-36.

[55] Rodríguez-Rodríguez, C.E., Marco-Urrea, E., Caminal, G. 2010a. Degradation of naproxen and carbamazepine in spiked sludge by slurry and solid-phase Trametes versicolor systems. Bioresource Technology, 101, 2259-2266.

[56] Rodríguez-Rodríguez, C.E., Marco-Urrea, E., Caminal, G. 2010b. Naproxen degradation test to monitor Trametes versicolor activity in solid-state bioremediation processes. Journal of Hazardous Materials, 179, 1152-1155.

[57] Rodríguez-Rodrígueza, C.E., Jelićd, A., Llorcad, M., Farréd, M., Caminala, G., Petrovićd, M., Barcelód, D., Vicent, T. 2011. Solid-phase treatment with the fungus Trametes versicolor substantially reduces pharmaceutical concentrations and toxicity from sewage sludge. Bioresource Technology, 102. 
[58] Saito, T., Kato, K., Yokogawa, Y., Nishida, M., Yamashita, N. 2004. Detoxification of Bisphenol A and Nonylphenol by Purified Extracellular Laccase from a Fungus Isolated from Soil. Journal of Bioscience and Bioengineering, 98, 64-66.

[59] Soares, A., Guieysse, B., Mattiasson, B. 2006. Influence of Agitation on the Removal of Nonylphenol by the White-rot Fungi Trametes versicolor and Bjerkandera sp. . Biotechnology Letters, 28, 139143.

[60] Songulashvili, G., Jimenéz-Tobón, G.A., Jaspers, C., Penninckx, M.J. 2012. Immobilized laccase of Cerrena unicolor for elimination of endocrine disruptors micropollutants. Fungal Biology, 116, 883-889.

[61] Suárez, S., Carballa, M., Omil, F., Lema, J. 2008. How are pharmaceutical and personal care products (PPCPs) removed from urban wastewaters? Reviews in Environmental Science and Bio/Technology, 7, 125-138.

[62] Suzuki, K., Hirai, H., Murata, H., Nishida, T. 2003. Removal of estrogenic activities of $17 \beta$-estradiol and ethinylestradiol by ligninolytic enzymes from white rot fungi. Water Research, 37, 19721975.

[63] Taboada-Puig, R., Junghanns, C., Demarche, P., Moreira, M.T., Feijoo, G., Lema, J.M., Agathos, S.N. 2011. Combined cross-linked enzyme aggregates from versatile peroxidase and glucose oxidase: Production, partial characterization and application for the elimination of endocrine disruptors. Bioresource Technology, 102, 6593-6599.

[64] Tadkaew, N., Hai, F.I., McDonald, J.A., Khan, S.J., Nghiem, L.D. 2011. Removal of trace organics by MBR treatment: The role of molecular properties. Water Research, 45, 2439-2451.

[65] Tamagawa, Y., Hirai, H., Kawai, S., Nishida, T. 2005. Removal of estrogenic activity of endocrinedisrupting genistein by ligninolytic enzymes from white rot fungi. FEMS Microbiology Letters, 244, 93-98.

[66] Torres-Duarte, C., Roman, R., Tinoco, R., Vazquez-Duhalt, R. 2009. Halogenated pesticide transformation by a laccase-mediator system. Chemosphere, 77, 687-692.

[67] Tran, N.H., Urase, T., Kusakabe, O. 2010. Biodegradation Characteristics of Pharmaceutical Substances by Whole Fungal Culture Trametes versicolor and its Laccase. Journal of Water and Environment Technology, 8, 125-140.

[68] Tsutsumi, Y., Haneda, T., Nishida, T. 2001. Removal of estrogenic activities of bisphenol A and nonylphenol by oxidative enzymes from lignin-degrading basidiomycetes. Chemosphere, 42 , 271-276.

[69] Wang, J., Majima, N., Hirai, H., Kawagishi, H. 2012. Effective Removal of Endocrine-Disrupting Compounds by Lignin Peroxidase from the White-Rot Fungus Phanerochaete sordida YK-624. Current Microbiology, 64, 300-303.

[70] Weng, S.-S., Ku, K.-L., Lai, H.-T. 2012. The implication of mediators for enhancement of laccase oxidation of sulfonamide antibiotics. Bioresource Technology, 113, 259-264.

[71] Yang, S. 2012b. Removal of micropollutants by a fungus-augmented membrane bioreactor. in: Environmental Engineering, Vol. MEng-Res University of Wollongong, Australia. Wollongong.

[72] Yang, S., Hai, I.F., Nyghiem, D.L., Roddick, F., Price, W.E. 2012a. Removal of trace organic contaminants by nitrifying activated sludge and whole-cell and crude enzyme extract of Trametes versicolour. Water Science and Technology, In press.

[73] Zhang, J., Liu, X., Xu, Z., Chen, H., Yang, Y. 2008. Degradation of chlorophenols catalyzed by laccase. International Biodeterioration \& Biodegradation, 61, 351-356.

[74] Zhang, Y., Geißen, S.-U. 2012. Elimination of carbamazepine in a non-sterile fungal bioreactor. Bioresource Technology, 112, 221-227. 
[75] Zhang, Y., Geißen, S.-U. 2010. In vitro degradation of carbamazepine and diclofenac by crude lignin peroxidase. Journal of Hazardous Materials, 176, 1089-1092. 


\section{List of figures}

Figure 1 Relative performance of whole-cell and extracellular enzyme preparations, and importance of cytochrome P450 system. Error bars indicate variation in data compiled from different independent studies [ $\mathrm{n}_{\text {whole-cell }}, \mathrm{n}_{\text {extracellular enzyme }}, \mathrm{n}_{\text {P450 }}$ : clofibric acid $[7,2,1]$, carbamazepine [7, 2, 1], naproxen $[7,2,1]$, ibuprofen $[7,2,1]$, estrone $[7,2,1]$, bisphenol A $[7,2,1]$, diclofenac $[7,2,1], 17 \alpha-$ ethynylestradiol [7, 2, 1], triclosan [7, 2, 1], nonylphenol [7, 2, 1]. Data source: (Auriol et al., 2008; Auriol et al., 2007; Cabana et al., 2007a; Cabana et al., 2007b; Cabana et al., 2009; Cajthaml et al., 2009; Eibes et al., 2011; Fukuda et al., 2001; Golan-Rozen et al., 2011; Hata et al., 2010; Hirano et al., 2000; Junghanns et al., 2005; Kim \& Nicell, 2006a; Kim \& Nicell, 2006b; Kurniawati \& Nicell, 2007; Lee et al., 2005; Lloret et al., 2010; Marco-Urrea et al., 2009; Marco-Urrea et al., 2010a; Marco-Urrea et al., 2010b; Marco-Urrea et al., 2010c; Murugesan et al., 2010; Okazaki et al., 2002; Rodarte-Morales et al., 2011; Rodarte-Morales et al., 2010; Rodríguez-Rodríguez et al., 2010a; Rodríguez-Rodríguez et al., 2010b; Rodríguez-Rodrígueza et al., 2011; Saito et al., 2004; Shin-ya et al., 2005; Soares et al., 2006; Subramanian \& Yadav, 2009; Suzuki et al., 2003; Tamagawa et al., 2005; Tran et al., 2010; Tsutsumi et al., 2001; Wang et al., 2012; Zhang \& Geißen, 2010) 


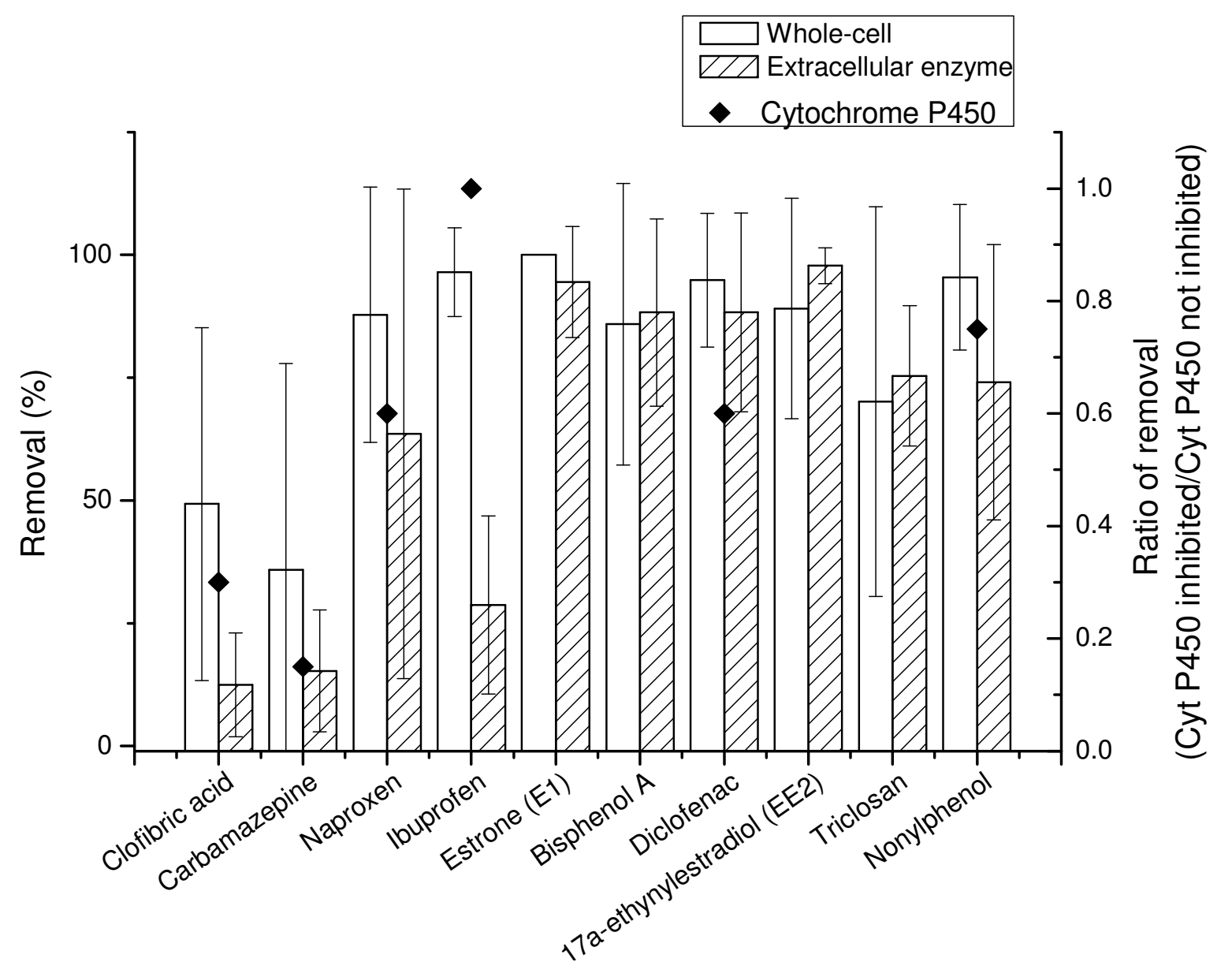

Figure 1 
Table 1 Representative examples of TrOC categories according to the presence of electron donating or electron withdrawing groups and their removal

\begin{tabular}{|c|c|}
\hline TrOC & Selected reference \\
\hline \multicolumn{2}{|c|}{$\begin{array}{l}\text { Category 1: Compounds with strong EDG and showing } \\
\text { mainly high removal }\end{array}$} \\
\hline Nonylphenol & $\begin{array}{l}\text { (Junghanns et al., 2005; Soares et al., } \\
\text { 2006) }\end{array}$ \\
\hline Bisphenol A & $\begin{array}{l}\text { (Cajthaml et al., 2009a; Hirano et al., } \\
\text { 2000; Lee et al., 2005) }\end{array}$ \\
\hline Bisphenol B & (Tsutsumi et al., 2001) \\
\hline Bisphenol F & (Tsutsumi et al., 2001) \\
\hline Estrone (E1) & (Golan-Rozen et al., 2011) \\
\hline $\begin{array}{l}17 \alpha-e t h y n y l e s t r a d i o l \\
(\mathrm{EE} 2)\end{array}$ & (Marco-Urrea et al., 2009) \\
\hline Dibutylphtahalate & $\begin{array}{l}\text { (Lee et al., 2004; Torres-Duarte et al., } \\
\text { 2009) }\end{array}$ \\
\hline \multicolumn{2}{|c|}{$\begin{array}{l}\text { Category 2: Compounds with EWG (in absence of strong } \\
\text { EDG) and showing mainly low removal }\end{array}$} \\
\hline Carbamazepine & $\begin{array}{l}\text { (Marco-Urrea et al., 2009; Rodríguez- } \\
\text { Rodrígueza et al., 2011; Tran et al., 2010) }\end{array}$ \\
\hline \multicolumn{2}{|c|}{$\begin{array}{l}\text { Category 3: Compounds with EDG and EWG and showing } \\
\text { mainly high removal }\end{array}$} \\
\hline Triclosan & (Cajthaml et al., 2009a) \\
\hline Sulfamethoxazole & $\begin{array}{l}\text { (Accinelli et al., 2010; Rodarte-Morales } \\
\text { et al., 2011) }\end{array}$ \\
\hline Sulfamethazine & (Rodríguez-Rodrígueza et al., 2011), \\
\hline Diclofenac & $\begin{array}{l}\text { (Lloret et al., 2010; Tran et al., 2010; } \\
\text { Zhang \& Geißen, 2010) }\end{array}$ \\
\hline Ibuprofen & $\begin{array}{l}\text { (Marco-Urrea et al., 2009; Rodarte- } \\
\text { Morales et al., 2011; Tran et al., 2010) }\end{array}$ \\
\hline Naproxen & $\begin{array}{l}\text { (Marco-Urrea et al., 2010a; Rodarte- } \\
\text { Morales et al., 2011; Tran et al., 2010) }\end{array}$ \\
\hline $\begin{array}{l}\text { Tetrachlorobisphenol } \\
\text { A }\end{array}$ & (Nicolucci et al., 2011) \\
\hline \multicolumn{2}{|c|}{$\begin{array}{l}\text { Category 4: Compounds with EDG and EWG and showing } \\
\text { mainly low removal }\end{array}$} \\
\hline Fluoxetine & $\begin{array}{l}\text { (Eibes et al., 2011; Rodarte-Morales et } \\
\text { al., 2011) }\end{array}$ \\
\hline Clofibric acid & $\begin{array}{l}\text { (Marco-Urrea et al., 2009; Tran et al., } \\
\text { 2010) }\end{array}$ \\
\hline Terbuthylazine & (Bending et al., 2002) \\
\hline Diuron & $\begin{array}{l}\text { (Bending et al., 2002; Torres-Duarte et } \\
\text { al., 2009) }\end{array}$ \\
\hline Atrazine & (Bending et al., 2002) \\
\hline Methoxychlor & (Hirai et al., 2004) \\
\hline Metalaxyl & (Bending et al., 2002) \\
\hline
\end{tabular}


Table 2 TrOC removal (\%) by different fungal species

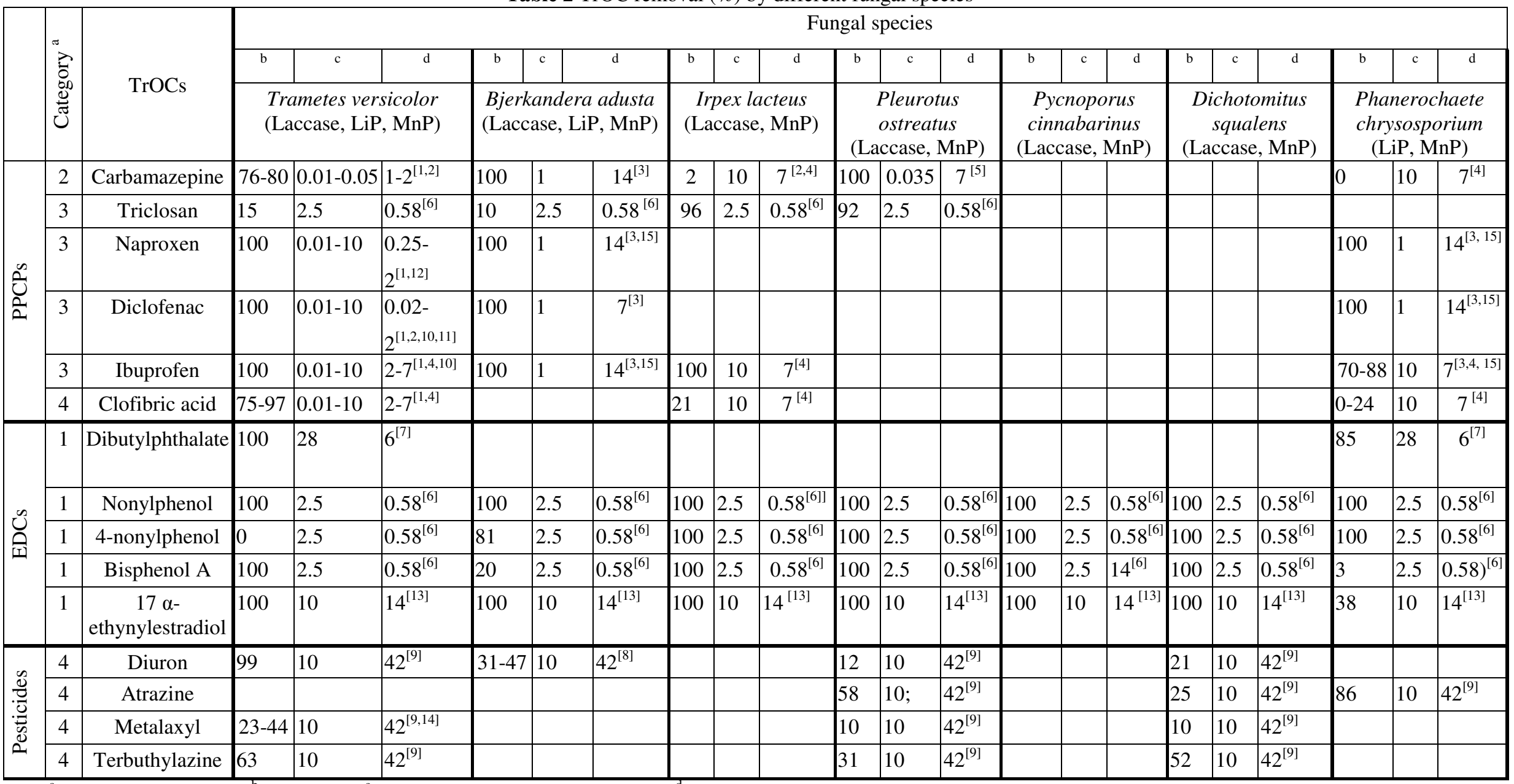

${ }^{\mathrm{a}}$ According to Table $1,{ }^{\mathrm{b}} \%$ removal, ${ }^{\mathrm{c}}$ initial TrOC concentration (mg/L), ${ }^{\mathrm{d}}$ incubation time (d)

References (for items b,c, d): ${ }^{[1]}$ (Tran et al., 2010) ; ${ }^{[2]}$ (Marco-Urrea et al., 2010b); ${ }^{[3]}$ (Rodarte-Morales et al., 2011); ${ }^{[4]}$ (Marco-Urrea et al., 2009) ; ${ }^{[5]}$ (GolanRozen et al., 2011); ${ }^{[6]}$ (Cajthaml et al., 2009a); ${ }^{[7]}$ (Lee et al., 2004); ${ }^{[8]}$ (Torres-Duarte et al., 2009); ${ }^{[9]}$ (Bending et al., 2002); ${ }^{[10]}$ (Rodríguez-Rodrígueza et al., 2011); ${ }^{[11]}$ (Yang et al., 2012); ${ }^{[12]}$ (Rodríguez-Rodríguez et al., 2010); ${ }^{[13]}$ (Cajthaml et al., 2009b); ${ }^{[14]}$ (Hirai et al., 2004); ${ }^{[15]}$ (Rodarte-Morales et al., 2010) 
Table 3 TrOC removal (\%) by different individual enzymes

\begin{tabular}{|c|c|c|c|c|c|c|c|c|c|c|c|}
\hline & \multirow{3}{*}{ Category $^{\mathrm{a}}$} & \multirow{3}{*}{ TrOCs } & \multicolumn{9}{|c|}{ Enzyme type } \\
\hline & & & $\mathrm{b}$ & $\mathrm{c}$ & d & $\mathrm{b}$ & $\mathrm{c}$ & d & $\mathrm{b}$ & $\mathrm{c}$ & d \\
\hline & & & \multicolumn{3}{|c|}{ Laccase } & \multicolumn{3}{|c|}{$\mathrm{LiP}$} & \multicolumn{3}{|c|}{$\mathrm{MnP}$} \\
\hline \multirow[t]{6}{*}{ PPCPs } & 2 & Carbamazepine & 37 & 0.01 & $48^{[1]}$ & $<10$ & 5 & $2^{[9]}$ & 14 & 4.7 & $24^{[12]}$ \\
\hline & 3 & Triclosan & 90 & 144 & $24^{[2]}$ & & & & & & \\
\hline & 3 & Naproxen & 100 & 0.01 & $48^{[1]}$ & & & & & & \\
\hline & 3 & Diclofenac & $65-100$ & 0.01 & $3-48^{[1,8]}$ & 100 & 5 & $2^{[9]}$ & & & \\
\hline & 3 & Ibuprofen & 38 & 0.01 & $48^{[1]}$ & & & & & & \\
\hline & 4 & Clofibric acid & 20 & 0.01 & $48^{[1]}$ & & & & & & \\
\hline \multirow[t]{5}{*}{ EDCs } & 1 & Nonylphenol & 100 & 22 & $1^{[5]}$ & & & & & & \\
\hline & 1 & Bisphenol A & $59-100$ & $0.5-27$ & $1-3^{[2,4,15]}$ & 50 & 22 & $8^{[10]}$ & 100 & $50-91$ & $1^{[13,14]}$ \\
\hline & 1 & Estrone & $64-100$ & $5-27$ & $1-8^{[6,8,16,17]}$ & & & & 100 & 5 & $8^{[6]}$ \\
\hline & 1 & 17 $\beta$-estradiol & 100 & $0.01-5$ & $1-8^{[7,8,16,17]}$ & 39 & 2.2 & $1^{[11]}$ & 100 & 2.96 & $1^{[7]}$ \\
\hline & 1 & $17 \alpha$-ethynylestradiol & 100 & 2.96 & $1^{[7]}$ & 41 & 22 & $8^{[10]}$ & 100 & 2.96 & $1^{[7]}$ \\
\hline Pesticide & 4 & Methoxychlor & 23 & 34.5 & $24^{[3]}$ & 28 & 34.5 & $24^{[3]}$ & 65 & 34.5 & $24^{[3]}$ \\
\hline
\end{tabular}

${ }^{\mathrm{a}}$ According to Table $1,{ }^{\mathrm{b}} \%$ removal, ${ }^{\mathrm{c}}$ initial TrOC concentration (mg/L), ${ }^{\mathrm{d}}$ incubation time (h)

Reference (for items b,c, d): ${ }^{[1]}$ (Tran et al., 2010); ${ }^{[2]}$ (Kim \& Nicell, 2006b); ${ }^{[3]}$ (Hirai et al., 2004); ${ }^{[4]}$ (Kim \& Nicell, 2006a); ${ }^{[5]}$ (Saito et al., 2004); ${ }^{[6]}$ (Tamagawa et al., 2005); ${ }^{[7]}$ (Suzuki et al., 2003); ${ }^{[8]}$ (Lloret et al., 2010); ${ }^{[9]}$ (Zhang \& Geißen, 2010); ${ }^{[10]}$ (Wang et al., 2012); ${ }^{[11]}$ (Mao et al., 2010); ${ }^{[12]}$ (Hata et al., 2010); ${ }^{[13]}$ (Tsutsumi et al., 2001); ${ }^{[14]}$ (Hirano et al., 2000); ${ }^{[15]}$ (Fukuda et al., 2001); ${ }^{[16]}$ (Auriol et al., 2008); ${ }^{[17]}$ (Auriol et al., 2007) 
Table 4 TrOC removal efficiencies by immobilized enzyme

\begin{tabular}{|c|c|c|c|c|c|c|}
\hline 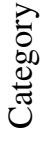 & TrOC & $\begin{array}{l}\text { Initial } \\
\text { concentration }\end{array}$ & Source of enzyme & Immobilization method & $\begin{array}{l}\text { Removal } \\
(\%)\end{array}$ & Reference \\
\hline \multirow[t]{4}{*}{3} & \multirow[t]{4}{*}{ Triclosan } & $50 \mu \mathrm{M}$ & Cerrena unicolour (laccase) & Immobilized on silica beads & $50(50)^{b}$ & (Songulashvili et al., 2012) \\
\hline & & $0.04 \mathrm{nM}$ & Coriolopsis polyzona (laccase) & Immobilized onto diatomaceous earth support & $80(16)$ & (Cabana et al., 2009) \\
\hline & & $100 \mathrm{mg} / \mathrm{L}$ & Coriolopsis polyzona (laccase) & Cross-linked enzyme aggregates & $\geq 80(2.3)$ & (Cabana et al., 2007) \\
\hline & & $10 \mathrm{mg} / \mathrm{L}$ & B. adusta (versatile peroxidase) & Cross-linked enzyme aggregates & $25(48)$ & (Taboada-Puig et al., 2011) \\
\hline \multirow[t]{4}{*}{1} & \multirow[t]{4}{*}{ Bisphenol A } & $50 \mu \mathrm{M}$ & Cerrena unicolor (laccase) & Immobilized on silica beads & $90(50)$ & (Songulashvili et al., 2012) \\
\hline & & $100 \mathrm{mg} / \mathrm{L}$ & Coriolopsis polyzona (laccase) & Cross-linked enzyme aggregates & $\geq 95(2.3)$ & (Cabana et al., 2007) \\
\hline & & $1 \mathrm{mM}$ & Trametes versicolor (laccase) & Immobilized on polyacrylonitrile beads & $92(1.5)$ & (Nicolucci et al., 2011) \\
\hline & & $10 \mathrm{mg} / \mathrm{L}$ & B. adusta (versatile peroxidase) & Cross-linked enzyme aggregates & $\geq 90(48)$ & (Taboada-Puig et al., 2011) \\
\hline \multirow[t]{4}{*}{1} & \multirow[t]{4}{*}{ Nonylphenol } & $50 \mu \mathrm{M}$ & Cerrena unicolour (laccase) & Immobilized on silica beads & $40(50)$ & (Songulashvili et al., 2012) \\
\hline & & $0.04 \mathrm{nM}$ & Coriolopsis polyzona (laccase) & Immobilized onto diatomaceous earth support & $85(16)$ & (Cabana et al., 2009) \\
\hline & & $100 \mathrm{mg} / \mathrm{L}$ & Coriolopsis polyzona (laccase) & Cross-linked enzyme aggregates & $\geq 95(2.3)$ & (Cabana et al., 2007) \\
\hline & & $10 \mathrm{mg} / \mathrm{L}$ & B. adusta (versatile peroxidase) & Cross-linked enzyme aggregates & $\geq 90(48)$ & (Taboada-Puig et al., 2011) \\
\hline \multirow[t]{4}{*}{1} & \multirow[t]{4}{*}{$17 \beta$-estradiol } & $10 \mu \mathrm{M}$ & Trametes versicolour (laccase) & Immobilized on the silica beads & $65(1)$ & $\begin{array}{l}\text { (Cardinal-Watkins \& } \\
\text { Nicell, 2011) }\end{array}$ \\
\hline & & $5 \mathrm{mg} / \mathrm{L}$ & $\begin{array}{l}\text { Myceliophthora } \\
\text { thermophila (laccase) }\end{array}$ & $\begin{array}{l}\text { Sol-gel matrix of } \\
\text { methyltrimethoxysilane and } \\
\text { tetramethoxysilane }\end{array}$ & $80(8)$ & (Lloret et al., 2011) \\
\hline & & $5 \mathrm{mg} / \mathrm{L}$ & $\begin{array}{l}\text { Myceliophthora thermophila } \\
\text { (laccase) }\end{array}$ & Immobilized on eupergit supports & $80(8)$ & (Lloret et al., 2012) \\
\hline & & $10 \mathrm{mg} / \mathrm{L}$ & B. adusta (versatile peroxidase) & Cross-linked enzyme aggregates & $\geq 90(48)$ & (Taboada-Puig et al., 2011) \\
\hline \multirow[t]{2}{*}{1} & \multirow[t]{2}{*}{ Estrone } & $5 \mathrm{mg} / \mathrm{L}$ & $\begin{array}{l}\text { Myceliophthora } \\
\text { thermophila (laccase) }\end{array}$ & $\begin{array}{l}\text { Sol-gel matrix of } \\
\text { methyltrimethoxysilane and } \\
\text { tetramethoxysilane }\end{array}$ & $60(8)$ & (Lloret et al., 2011) \\
\hline & & $5 \mathrm{mg} / \mathrm{L}$ & $\begin{array}{l}\text { Myceliophthora thermophila } \\
\text { (laccase) }\end{array}$ & Immobilized on eupergit supports & $65(8)$ & (Lloret et al., 2012) \\
\hline \multirow[t]{3}{*}{1} & \multirow[t]{3}{*}{$\begin{array}{l}17 \alpha- \\
\text { ethynylestradiol }\end{array}$} & $5 \mathrm{mg} / \mathrm{L}$ & $\begin{array}{l}\text { Myceliophthora thermophila } \\
\text { (laccase) }\end{array}$ & $\begin{array}{l}\text { Sol-gel matrix of methyltrimethoxysilane and } \\
\text { tetramethoxysilane }\end{array}$ & $60(8)$ & (Lloret et al., 2011) \\
\hline & & $5 \mathrm{mg} / \mathrm{L}$ & $\begin{array}{l}\text { Myceliophthora thermophila } \\
\text { (laccase) }\end{array}$ & Immobilized on eupergit supports & $80(8)$ & (Lloret et al., 2012) \\
\hline & & $10 \mathrm{mg} / \mathrm{L}$ & B. adusta (versatile peroxidase) & Cross-linked enzyme aggregates & $\geq 90(48)$ & (Taboada-Puig et al., 2011) \\
\hline
\end{tabular}

\footnotetext{
${ }^{\mathrm{a}}$ According to Table 1
${ }^{\mathrm{b}}$ Value in parentheses indicates incubation time (h)
} 